
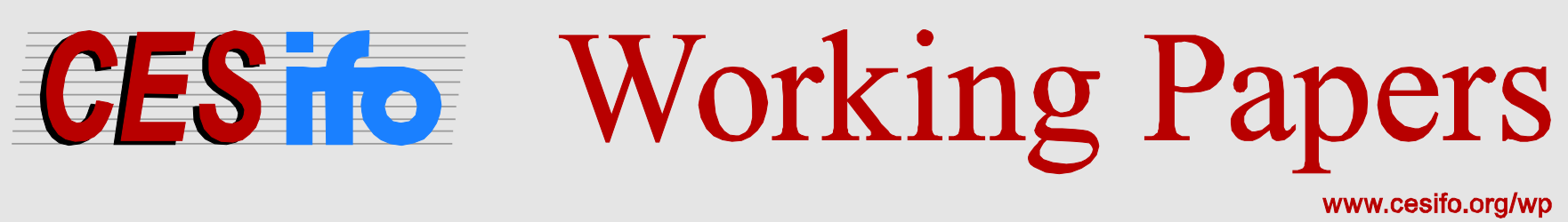

\title{
Of Morals, Markets and Mice: A Comment on Falk and Szech
}

\author{
Friedrich Breyer \\ Joachim Weimann
}

CESIFO WORKING PAPER NO. 4745

CATEGORY 13: BEHAVIOURAL ECONOMICS

APRIL 2014

An electronic version of the paper may be downloaded

- from the SSRN website:

- from the RePEc website:

- from the CESifo website:

wWw.SSRN.com

Www.RePEc.org

www.CESifo-group.org/wp

\section{CESifo}




\title{
Of Morals, Markets and Mice: A Comment on Falk and Szech
}

\begin{abstract}
A recent experimental study by Falk and Szech (Science, 2013) concludes that „markets erode moral values”. If this were true, economists, who have emphasized the efficiency enhancing effects of markets for centuries, would have to reconsider their judgments fundamentally. This would be no less than a revolution in normative economics. In this note we demonstrate that the claim made by Falk and Szech is unfounded and that their experimental results can be (and should be) interpreted in exactly the opposite way.
\end{abstract}

JEL-Code: D010, D030, D630.

Friedrich Breyer

University of Konstanz

Germany

friedrich.breyer@uni-konstanz.de
Joachim Weimann

University of Magdeburg

Germany

joachim.weimann@ww.uni-magdeburg.de 


\title{
Of Morals, Markets and Mice: A comment on Falk and Szech
}

\author{
Friedrich Breyer, University of Konstanz \\ Joachim Weimann, Otto-von-Guericke-University Magdeburg
}

August 2013

In a recent issue of Science, Armin Falk and Nora Szech [2013 a, 2013 b] published the results of a very interesting experiment that employed a new and fascinating design to evaluate the effects of markets on moral values. The main conclusion of their work is that „markets erode moral values". This article met with great interest in the media, at least in Germany. Several daily newspapers reported on it and the authors were invited to appear on TV shows for discussions with moral philosophers. ${ }^{1}$ In addition, the Huffington Post reported on it with an article bearing the headline: "Markets Erode Morals, Let People Do Horrible Things: Study". ${ }^{2}$ The message seemed to confirm the widespread sentiment - originating from the financial crisis - that markets should be seen with great skepticism. Indeed, if it is true that markets erode moral values, economists, who have emphasized the efficiency enhancing effects of markets for decades, if not centuries, would have to reconsider their judgments fundamentally. This would be no less than a revolution in normative economics. In this comment we want to demonstrate that the experimental results described by Falk and Szech can be (and should be) interpreted in exactly the opposite way and that the experimental design used by Falk and Szech could be improved.

The experiment of Falk and Szech was conducted in Bonn, Germany, in May 2012 with 787 participants. The issue was the choice between receiving money (up to 20 Euros) for allowing a laboratory mouse to be killed or forgoing the money and saving the life of the mouse. There were three different treatments. In treatment one, called "individual", subjects could decide either to get 10 euros or to save the mouse. Treatment two, "bilateral market", defined a more complicated structure in which the experimenter offered two players a total of 20 euros if they agreed to let a mouse be killed, and introduced a bargaining period in which the players essentially bargained how to divide the proceeds of this trade between them. ${ }^{3}$ The third treatment, "multilateral market", had the same structure, but with more than two players involved. The authors compare the "fractions of subjects who were willing to kill a mouse for monetary amounts below or equal to 10 euros" (ibid., p.707, heading of Figure 1). ${ }^{4}$ As this fraction was significantly higher in the latter treatments than in the "individual" treatment, the authors con-

\footnotetext{
${ }^{1} \mathrm{http}: / / \mathrm{www} . c e n s . u n i-b o n n . d e / t e a m /$ board/armin-falk/press-releases-and-articles.

${ }^{2} \mathrm{http}: / / \mathrm{www}$. huffingtonpost.com/2013/05/13/markets-morals-study_n_3267995.html

${ }^{3}$ In order to suggest that this bargaining procedure is a market transaction, the two players are named "seller" and "buyer" of the mouse, respectively, but this characterization is misleading since the roles of the players are completely symmetric.

${ }^{4}$ The expression "willing to kill a mouse" is misleading because subjects did not have to kill the mouse themselves. The correct wording would have been "willing to let a mouse be killed".
} 
clude that "market interaction displays a tendency to lower moral values, relative to individually stated preferences" (p.710, col. 2).

We have three major objections concerning the results and their interpretation by Falk and Szech, where our focus will be on a comparison of treatments one and two:

1. If we accept the criterion that Falk and Szech propose to compare the results of the different treatments, the economically correct interpretation is precisely the opposite: treatment one is a typical market situation, while treatment two is not.

2. Moreover, if a different (and more appropriate) criterion of comparison is chosen, namely the share of mice killed, no significant differences between treatments one and two can be found.

3. The comparison of treatment one (individual) with treatments two and three (bargaining) does not allow clear conclusions because a) more than one treatment parameter was changed, b) the individual normative predisposition of the subjects was not controlled and c) the payoff mechanism was changed.

It is worth mentioning that our critique does not aim at the external validity of the experimental results - which is a quite general problem with laboratory experiments. Quite to the contrary, we are questioning their internal validity, i.e. we doubt that the authors have interpreted their own results correctly.

\section{Objection 1: The interpretation of the data}

What is a typical market situation? Economists distinguish between different market forms characterized by the degree of competition. But in nearly all of these forms and, in particular, in competitive markets, consumers behave as price takers. This means they only decide whether or not to buy a good at a given price. Bargaining over prices does not take place in typical market situations. Consumers do not have any strategic leeway, but they just adapt their behavior to the given price. This also holds for decisions with an explicit moral component. Imagine someone who wants to buy a chocolate bar and finds a variety of "regular" chocolate and "fair traded" chocolate at the supermarket. Then she has to decide whether or not to pay the higher price for the fair-trade product knowing that the extra charge is a transfer payment to producers in developing countries. Once again, there are no negotiations and there is no bargaining; there is simply an individual decision. Thus treatment one (individual) in the Falk and Szech paper describes a typical market decision of a consumer who behaves as a price taker. The offer is: paying a price of 10 euros for saving the life of a mouse. The price is fixed and subjects only have to decide whether to buy the life of the mouse or not. This is exactly the same decision our chocolate consumer has to take when she chooses between regular and fair traded chocolate. 
Falk and Szech run the "individual" treatment also in a slightly different way. In the "price list treatment" subjects were offered a list of increasing prices and they had to decide at what price they would prefer to get the money instead of saving the life of the mouse. The results of this treatment are identical with the "individual" treatment. This finding makes our point even more transparent:

The price list treatment makes use of a well-known procedure which is normally used to get information about the true willingness to pay for a particular item. The advantage of the price list procedure is that it is incentive compatible: Given that the price is chosen at random, it is the best answer to state the true willingness to pay. And this is the best answer, because the subject is in the position of a price taker. It is rational to state the true preference because she cannot influence the price which is randomly chosen. Thus, it is not surprising that the price list treatment reproduces the results of the individual treatment. In both treatments subjects behave as they do in most of the markets they are confronted with during their lifetime: they respond to a given price.

On the other hand, economists know that small group bargaining situations differ tremendously from the typical market situation described above. The crucial point here is that in a typical bargaining situation the players have private information that they could use for strategic behavior. For example, each bargainer knows his own reservation price but not the corresponding price of his counterpart. If the strategic leeway given by this private information is used, then it is not certain that the bargaining process will end up in an efficient solution (Myerson and Satterthwaite 1988). Even in very simple two-person bargaining situations such as the famous ultimatum game (Güth et al. 1983) experimental economists have observed very surprising results that differ strongly from what would be expected from a market outcome. Therefore, treatments two and three in the Falk/Szech paper do not describe typical market situations but the exact opposite. Bargaining does not usually take place in competitive markets $^{5}$ but rather outside markets. Examples are collective wage bargaining, bargaining in the political sector or bargaining between nations.

We do not dispute that the double auction (DA) is indeed an institution that is able to reproduce market outcomes. This is why we argue (in our second point) that the outcomes of the institutions should be compared and not the stated willingness to pay. And the outcomes of the treatments "price list" and "double auction" do not differ. Furthermore, we still do not think that the DA used in the experiment can be treated as a typical market situation. First, although auctions have a growing importance in e-business, most of these auctions are not double auctions but have other designs (eBay uses a second price auction). Second, the DA

\footnotetext{
${ }^{5}$ Of course there are exceptions, such as the bilateral negotiation over the price for a used car. But economists know that these cases cannot be characterized as typical market situations because information asymmetries provoke inefficient solutions and other problems (like adverse selection (Akerlof 1973) ) that do not occur in "typical" markets.
} 
used by Falk \& Szech has a very special feature. In this auction, the surplus that has to be divided between the two players is fixed (20 euro) and known to both players. This is equivalent to a situation in which a buyer and a seller know the difference between the maximal willingness to pay of the buyer and the reservation price of the seller. To our knowledge, markets in which this is the case are extremely rare. Therefore, we do not accept that the "market treatment" used by Falk \& Szech is representative of real markets. Instead it is the "individual treatment" that really represents markets.

If we accept the criterion of comparison proposed by Falk and Szech, namely the share of subjects agreeing on the death of a mouse for 10 euros or less, which is $45.9 \%$ in treatment one and $72.2 \%$ in treatment two, the right interpretation is exactly the opposite to the one given by the authors: in typical market situations, moral norms play a more prominent role than in non-market bargaining situations.

\section{Objection 2: A more appropriate criterion for comparing the treatments}

Ultimately, the moral evaluation of institutions such as markets or bilateral bargaining arrangements should be based on the results brought about by these institutions. In this case, the relevant result is not what offers subjects make or accept in the process of bargaining, but how many mice are killed. Yet by this measure, treatments one and two do not differ significantly since the shares of mice killed are $45.9 \%$ and $47.7 \%$, respectively. Thus no matter what labels are used to characterize the institutions created by Falk and Szech in their lab experiment, there is no significant difference in the only measure that is available as a carrier of moral value.

Falk \& Szech argue that even if they employ market outcomes as a measure, the outcome in the bilateral market is worse than in the individual treatment. The percentage of subjects willing to kill a mouse for 10 euro or less in the individual treatment is $45.9 \%$. Falk \& Szech conclude: "The expected fraction of killed mice in a given market period should thus roughly equal 45.9 percent $* 45.9$ percent $=21.1$ percent in the bilateral market." But this is wrong, because in a bilateral trade only one trader is needed with a WTP of less than 10 euro. On the other side of the market there can be a subject with a higher WTP. Thus the right way to compute the number of trades possible in the individual treatment would be to check how many combinations with a total WTP of 20 euro or less can be found.

Once again it should be emphasized that no matter how the performance of the treatments is measured, the individual and the price list treatments are the true market treatments. Thus if any measure shows that in these two treatments moral values are stronger than in the DA treatments, this is an argument in favor of and not against markets. 


\section{Objection 3: The comparison of the treatments}

Economists use a simple method to investigate things experimentally. They design treatments that differ in only one specific aspect from each other and then compare behavior in these treatments. If subjects behave differently between treatments, it can be reasoned that the treatment differences are important for individual behavior. Obviously, such reasoning is impossible if more than one design element is changed at the same time. This is the case in the Falk and Szech experiment. There are at least three important design elements that change from treatments one to two and three.

First, the price setting mechanism is changed. While in treatment one the price is fixed, in the other two treatments the price is established in a collective bargaining process in which asymmetric information and strategic behavior play an important role (see above). Second, the number of people who decide whether the mouse dies is changed. This is important because, as we know from other experiments, groups decide differently from individuals (Kerr and Tindale 2004, Kocher and Sutter 2005). One reason for this may be that for collective decisions the (moral) responsibility is diluted.

A third change pertains to the payout rule. While in treatment one the question was asked only once and there was certainty that the amount earned in that round would be paid out, subjects in treatments two and three played the same game 10 times and only one randomly chosen round was used for payout. Therefore, participants in a particular bargaining round knew that there was only a 10 per cent chance that they would actually earn the amount agreed on in that round.

If the change of institutions covers the change of totally different aspects of a decision situation, it is crucial to be able to identify which of these aspects are responsible for the change in behavior. Falk and Szech interpret their results in exactly this sense because they identify the market environment as being responsible for the change in the stated willingness to pay. By doing so, they exclude other "specific reasons", that might be of importance (number of people involved in the decision, the framing, the bargaining mechanism, the random payout mechanism, the fact that one subject is called the "owner" of the mouse and so on). How important these other specific reasons are is emphasized by Falk \& Szech themselves when they point out that the killing rate in the multilateral treatment of the DA was much higher than in the bilateral one.

The comparison of the treatments used by Falk and Szech is problematic for a third reason. The benchmark for moral values is formed by "individually stated preferences" (Falk and Szech 2013, p.710). But individual preferences for the life of animals were not controlled, although these preferences may vary a lot depending on an individual's life circumstances or 
other moral values. In particular, subjects were not asked before the experiment if they found killing mice morally wrong. ${ }^{6}$

\section{Concluding Remarks}

We conclude that the claim made by Falk and Szech (2013) that "markets erode moral values" is not at all supported by the results of their experiments. Their results demonstrate nicely that in the case of a typical market decision, consumers simply follow their preferences and that under these conditions moral values play an important role. In the case of bilateral bargaining, preferences-driven behavior is superimposed by strategic reasoning and therefore more subjects reveal a willingness to pay less than ten euros for the life of a mouse. More importantly, however, if what people do counts rather than what they say, there is no difference between these settings.

\section{Acknowledgements}

The authors are grateful to Mathias Kifmann and Ronnie Schöb for valuable comments.

\section{References}

Akerlof, G.A. (1970), The Market for "Lemons": Quality Uncertainty and the Market Mechanism. The Quarterly Journal of Economics, Vol. 84, No. 3., 488-500.

Falk, A. and N. Szech (2013a), Morals and Markets, Science 340, 707-711.

Falk, A. and N. Szech (2013b), Supplementary Materials for "Morals and Markets", www.sciencemag.org/cgi/content/full/340/6133/707/DC1.

Güth W., R. Schmittberger, B. Schwarze (1982), An experimental analysis of ultimatum bargaining. Journal of Economic Behavior and Organization, 3, 367-388.

Kerr, N. L., R. S. Tindale (2004), Group Performance and Decision Making, Annual Review of Psychology, 55. 623 - 655.

Kocher, M. G., M. Sutter (2005), The Decision Maker Matters: Individual Versus Group Behaviour in Experimental Beauty-Contest Games, The Economic Journal, 115, 200 - 223.

Myerson, R.B. and M.A. Satterthwaite (1983), Efficient Mechanism for Bilateral Trading, Journal of Economic Theory 29, 265-281.

\footnotetext{
${ }^{6}$ Nor were they asked if they possessed a cat and if this cat regularly killed mice.
} 